\title{
Adana ve Kuzey Kıbrıs’ta Yer Alan Camiye Dönüştürülmüş Kilise Yapıları Üzerine Bir Karşılaştırmalı Çalışma
}

\author{
Hülya YÜCEER ${ }^{* 1}$ \\ ${ }^{1}$ Adana Bilim ve Teknoloji Üniversitesi, Güzel Sanatlar Tasarım ve Mimarlık Fakültesi, \\ Mimarlık Bölümü, Adana
}

Geliş tarihi: 13.06.2016

Kabul tarihi: 23.11.2016

$\ddot{O} z$

Dini olarak kutsal kabul edilen yerlerin farklı bir dinin mensupları tarafından kullanılması, amaç ve süreçleri farklı olsa da, tarih içinde süregelmiş bir uygulamadır. Bu uygulama, bazı durumlar için kültürel fetih olarak yorumlanabileceği gibi, kimi durumlarda da yerin kutsallı̆̆ını bozmadan sadece ibadet edecek bir yer gereksinimine yanıt vermek üzere yapılmış uygun bir adaptasyon olarak kabul edilebilir. Farklı kültürlerin kutsal yerleri kendileme süreçleri, bu kültürleri ve zaman içinde değişimlerini okumak için ilginç bir kaynak oluşturmaktadır. Bu çalışmanın amacı, Adana ve Kuzey Kıbrıs'ta yer alan kilise yapılarının ibadet amaçlı yeniden kullanım süreçleri üzerinden kültürel miras ve çağdaş kültürel dinamikler arasındaki ilişkiyi okumaktır.

Anahtar Kelimeler: Mimari koruma, Tarihi yapıların yeniden kullanımı, Kilise, Cami, Adana, Kıbrıs

\section{A Comparative Study for the Appropriation of Church Buildings in Adana and Northern Cyprus}

\begin{abstract}
The appropriation of places of worship by communities associated with different religions has been a common practice throughout history, although the aims of and processes for such appropriations may vary. In some cases, it can be interpreted as a cultural conquest. Alternatively, it can be a convenient adaptation to provide a space for prayer while maintaining the sanctity of the place. The process of appropriation provides an understanding of cultures and their change over time. This study aims at tracing the relationship between heritage and contemporary cultural dynamics by examining the process of the appropriation of church buildings in Adana and Northern Cyprus.
\end{abstract}

Keywords: Reuse of historic buildings, Appropriation of heritage sites, Church, Mosque, Adana, Cyprus

\footnotetext{
*Sorumlu yazar (Corresponding author): Hülya YÜCEER, hyuceer@abtu.edu.tr
} 


\section{GíRiş}

Tarihsel süreç içinde, farklı kültürler üzerine medeniyet inşa eden toplumların fethettikleri yerlerdeki yapıları farklı işlevler vererek yeniden kullanmaları ya da buldukları yıkık yapıların malzemeleri ile yeni yapı inşa etmeleri bir yaygın uygulamadır [1, 2, 3]. Yapı türleri arasında ibadet amaçlı kullanılanların yeniden işlevlendirilmeleri dini değerinden dolayı hassasiyet taşımakla birlikte, tarih içinde bu durumu örnekleyecek pek çok uygulama olduğu bilinmektedir [4,5]. Hatta bazı yapılar art arda farklı kültürlerce pek çok kez yeniden dönüştürülmüştür. Örneğin, İspanya'daki Kordoba Katedrali/Cami, bir pagan tapınağ üzerine Vizigotlar tarafından 6. yüzyılda Katolik kilisesi olarak inşa edilmiş, Emevilerin İber yarımadasını fethinin ardından 711-784 yılları arasında iç mekanı ikiye bölünerek hem Müslümanlara hem de Hiristiyanlara ibadet yeri olmuştur [6,7]. 784 yılında, bir kısmı yeniden inşa edilerek, yapının tamamı cami olarak kullanılmıştır. 1236 yılında tekrar kiliseye çevrilen yap1 günümüzde hala bu işlevini sürdürmektedir.

Yüzyıllardır farklı medeniyetlerin hüküm sürdüğü Anadolu toprakları da bu tür dini yapılara pek çok örnek barındırmaktadır. 537 yılında kilise olarak inşa edilmiş, İstanbul'un fethinin ardından camiye dönüştürülen ve 1935 yılından itibaren müze olarak kullanılan Ayasofya Katedrali ülkemizde konuyla ilgili en iyi bilinen örnektir. İbadet dışında işlev verilmiş kiliselerin yanı sıra, sadece İstanbul'da camiye çevrilmiş 28 kilise bulunmaktadır [8,9]. İstanbul dişında, Trabzon, Ayvalık, Kars, Adana illerinde ve Kuzey Kıbris'ta da Osmanlı döneminde ya da mübadele sonrasında camiye çevrilmiş kiliselere rastlamak mümkündür. Kibris'ta bu tür uygulamalar Osmanlı İmparatorluğu'nun adayı fethi olan 1571 yılından beri yapılmaktadır. Osmanlılar fetih sonrası Kıbrıs'taki kiliselerin bir kısmını camiye dönüştürmüşler ve bunun için iyi mimarlarını görevlendirmişlerdir. En iyi bilinen yapılar, başkent Lefkoşa'daki Selimiye Camisi (St. Sophia Katedrali) ve Gazimağusa'da yer alan Lala Mustafa Paşa Camisidir (St. Nicholas Katedrali). Latin Katolik Kilisesi için önem arz eden bu iki katedral hala cami olarak kullanılmaktadır. Bunun yanı sıra, 1974 yılında adanın ikiye bölünmesi sonucu yaşanan zorunlu göç ve belirsizlik sürecinde kuzeye yerleştirilen Türk halkı artık kullanıcısı olmayan kiliselerin bir kısmını camiye dönüştürmüşlerdir. Bugün Kuzey Kıbrıs'ta hala çok sayıda camiye dönüştürülmüş veya farklı işlev verilmiş kilise bulunmaktadır.

Somut kültürel mirasımızın örnekleri olan ve ülkemiz coğrafyasının kültürel çeşitliğinin somut kanıtları kilise yapılarının camiye çevrilmesi veya farklı işlevler verilmesi kültürel mirasın korunması çalışmalarının tartışmalı konularından biridir. $\mathrm{Bu}$ konuda ülkemizde yapılan çalışmalar sınırlı sayıda olup [8-11] daha çok yabanc1 kaynak bulunmaktadir [4-7,12-21]. Mevcut ulusal ve uluslararası kaynaklarda dini yapıların farklı amaçlarla kullanılması daha çok mimari değerlendirme, savaş sırası ve sonrasında dini yapıların hedef alınması, din olgusunun değer kaybettiği ülkelerde ihtiyaç fazlası kiliselerin yeniden kullanımları konularını işlemektedir. Bu çalışmanın amacı ise literatürdeki açık konulardan dini yapıların farklı inanç sahibi bir toplum tarafından adaptasyon süreçlerinin incelenerek kültürel mirasın içselleştirmesi (kendilemeappropriation) teorisine katkıda bulunmaktır. Sosyal bilimlerde farklı alanlarda da kullanılan bu teorik temel, mimarlık alanında tarihi yapıların farklı kültürlerce özgün işlevi dışında kullanımı, dolayısıyla yapısal ve sosyal olarak adaptasyonlarını içermektedir. Koruma alanında ayrıca kültürel miras algısı ve kültürel mirası sahiplenme konularında yeri vardır. Konu, bulunduğumuz coğrafya içindeki kiliseler özelinde irdelendiğinde fetihler, savaşlar ve göçler sonrasında bu yapıların yıkıldığı, camiye dönüştürüldüğü veya farklı bir işlev verildiği anlaşılmaktadır. Dolayısıyla, tarihsel olayların siyasi ve sosyal dinamikleri kiliseden camiye dönüştürülme süreçlerinde farklılıklara yol açmıştır. $\mathrm{Bu}$ farklılıkları izlemek, dönüştürülme sürecinin doğru tanımlanması ve kilise yapılarının kültürel miras stoku içindeki yerini belirlenmesinde önem taşımaktadır. Bu nedenle, çalışmada çok sayıda örnek barındıran Kuzey Kıbrıs ve az sayıda örneğin bulunduğu Adana'daki kilise yapıları incelenmiştir. Örnek yapılar öncelikle kendi bağlamlarında irdelenmiş ve daha 
sonra dönüştürülme süreçleri benzerlik ve farklılıklarıyla nedenleri tartışılarak açıklanmıştır.

Çalışmanın bulguları arşiv, literatür araştırması ve saha çalışmasına dayanmaktadır. Yöntem olarak öncelikle Adana ve Kuzey Kıbrıs'ta yer alan kilise yapıları tescil ve korunmalarından sorumlu kamu kurumlarındaki listelerden tespit edilmiş ve envanter fişleri incelenmiştir. Bu yapılar hakkında ayrıntılı bilgi edinmek için literatür araştırılmıştır. Kuzey Kıbrıs'taki yapıların yerinde tespit ve incelemesi 2015 yılı Temmuz ve Ağustos aylarında, Adana kent merkezindeki yapılar MartNisan 2015, ilçelerdeki yapılar ise Ekim-Kasım 2015 aylarında yapılmıştır.

Çalışma 5 ana bölümden oluşmaktadır. Giriş bölümünde çalışmanın amacı, literatürdeki eksik alanlar kapsam ve yöntem açıklanmaktadır. Bulgular ikinci ve üçüncü bölümde sunulmuştur. Kuzey Kıbrıs'taki yapılar ikinci bölümde, Adana'daki yapılar ise üçüncü bölümde incelenmiştir. Dördüncü bölümde, yapıların kiliseden camiye dönüştürülme süreci, bu yapıların kendi bağlamlarında kültürel miras olarak nasıl algılandıkları ve korunmalarıla ilgili değerlendirmeler karşılaştırmalı olarak tartışılmaktadır. Sonuç bölümünde yapıların bütüncül korunmaları ile ilgili öneriler sunulmuştur.

\section{KUZEY KIBRIS}

Kıbrıs adası tarihte Hıristiyanlığın ilk yayıldığ yerlerden biri olup (MS 45), İslamiyet 649 yilında Arapların adayı almasıyla yayılmaya başlamış, ancak adanın haçlılara geçmesinden sonra kısıtlanmıştır. Bugün adada yer alan İslam dini eserlerinin büyük çoğunluğu Osmanlıların 1570 yllındaki fethinden sonra inşa edilmiştir. Kilise, manastır, şapel gibi Hıristiyanlığı temsil eden yapılar ise Bizans, Rum Ortodoks, Lüzinyan, Latin, Maronit, Ermeni ve İngiliz toplumlar tarafindan inşa edilmiş ibadet yerleridir. $\mathrm{Bu}$ yapıların bir kısmı Osmanlılar, bir k1smı ise 1974'te adanın ikiye bölünmesinden sonra Türk toplumu tarafindan camiye çevrilmiştir. Kuzey Kıbrıs'ta kiliseden camiye dönüştürülen yapılar bu bölümde üç alt başlıkta incelenmiştir. Öncelikle Kıbrıs'ın kısaca tarihi hakkında bilgi verilmiş, daha sonra Kibris'sn dini mirası değerlendirilmiştir. Üçüncü alt başlıkta ise kiliseden camiye dönüştürülme süreci 1974 öncesi ve sonrası dönem ele alınarak açıklanmıştır.

\subsection{Kıbrıs'ın Kısa Tarihi}

Afrika, Asya ve Avrupa kıtalarını bağlayan deniz yolu üzerindeki konumuyla stratejik pozisyona sahip olan Kıbrıs, tarihi boyunca pek çok farklı uygarlığa ev sahipliği yapmıştır. Bu uygarlıklardan ilki MÖ 1. yüzyılda hüküm süren Fars-Fenike ve Helenistik Misır Ptolemaios topluluklarıdır. MÖ 58 ile MS 395 yılları arasında Romalılar hakim olmuş, sonrasında ada Bizans İmparatorluğu'nun yönetimi altındayken, geçici olarak iki kez Suriye kökenli Müslüman Arap toplum Sarakanlar tarafindan işgal edilmiştir [22]. Kıbrıs, 1191 yılında, İngiltere kralı 1. Richard önderliğindeki haçlı kuvvetleri tarafından fethedilmiş ve daha sonra yönetim Fransız haçlı komutanı ve Kudüs kralı Guy de Lüzinyan ile onun soyundan gelenlere devredilmiştir [23].

1489 yılında, son Lüzinyan kralı 2. James öldükten sonra, Kıbrıs adası eși kraliçe Catherine Cornaro tarafindan Venedik İmparatorluğu'na devredilmiştir. Venedik hakimiyetinde (1489-1571) adaya çok sayıda Arnavut yerleşmiş ve Limasol'da Arnavut Mescidi'ni inşa etmişlerdir [23]. Kibris'in 1570-1571 yilında Osmanlilar tarafindan fethi sonrasında, adadaki Lüzinyanların ve Venediklerin hükmü altında süregelen feodal sistem kaldırılmış, Anadolu göçmenlerini Kıbrıs'a yerleşmeye yönlendirilen derebeylik sistemi kurmuluştur [24]. 1878 yılında Kıbrıs, Osmanlılar tarafindan, 1958'e kadar adayı yöneten İngiliz Hükümeti'ne kiralanmıştır.

1960 yılında Kıbrıs Cumhuriyeti'nin kurulması ile beraber ada İngilizlerin hakimiyetinden kurtularak bağımsızlığını ilan etmiştir. Ancak, kısa bir süre sonra, 1963'de adanın iki etnik grubu olan Rumlar ve Türkler arasında anlaşmazlıklar ortaya çıkmıştır [25]. 1974 yılında Türk ordusunun müdahalesiBarış Harekatı- sonrasında, adanın ikiye bölünerek Türk ve Rum toplumlarının ayrılmasını ve adanın 
kendilerine ayrılan bölümüne zorunlu göç etmelerini öngören karar alınmıştır [26]. 1974 yılından bugüne dek iki topluluk, Birleşmiş Milletler kontrollü tampon bölgenin iki tarafında ayrı olarak yaşamaktadır. 1974'deki bölünmeden sonra Türk ve Rum nüfusunun çoğu göç etmiş olmasına rağmen hala az sayıda bulundukları yerlerden ayrılmamış aile bulunmaktadır. Bölünme sonrası güneyde 1960 yılında kurulmuş olan Kıbrıs Cumhuriyeti varlığını sürdürmeye devam ederken, 1974-1983 yılları arası Kuzey Kıbrıs bir federe devlet olarak yönetilmiştir. 1983 yılında ise Türkiye ile birlikte bugün hala az sayıda ülke tarafından tanınan Kuzey Kıbrıs Türk Cumhuriyeti kurulmuştur.

\subsection{Kıbrıs'ta Dini Mirasın Oluşumu}

Kıbrıs'ın somut dini mirası, Lüzinyanlar, Venedikler, Nestoryanlar, Maronitler, Ermeniler ve Osmanlılar başta olmak üzere tarih boyunca adada yaşamış çeşitli kültürlerinin eserlerinden oluşmaktadır $[27,28]$. Ada ilk tek tanrılı din izleri erken Hristiyanlık dönemindedir. MS 45 yılında Antakya Kilisesi, Aziz Paul ve Aziz Barnabas'1, Barnabas'ın yeğeni John Mark eşliğinde Kıbrıs'a ilk Hıristiyan misyonerleri olarak göndermiştir. St. Paul ve St. Barnabas dönemin Roma valisi Sergius Paulus'un Hristiyanlık dini kabul etmesinde önemli rol oynamıştır [29]. Hristiyanlığın kabulünden sonra bugün hala az sayida var olan Pagan tapınakları ve diğer kutsal yapıların yerine kilise ve manastırlar inşa edilmiştir. Hıristiyanlığın mezheplerinden Ortodoks Kilisesi, Kıbris'in Bizans İmparatorluğu tarafindan yönetildiği 4. yüzyıldan bugüne dek hala adadaki en baskın Kilise durumdadır [23,29]. Ancak bu durum Lüzinyan ve Venedik hükümdarlığı altında 1191 ile1571 yılları arası bir süre kesintiye uğramıştır [30]. Bu dönemde, adanın önemli kentlerinde Akdeniz bölgesinde görülen Latin kilisesi mimarisine benzer katedral ve kiliseler ile yüksek rakımlı yerlerde manastırlar inşa edilmiştir. En belirgin örnekler Kudüs Kralı'nın atandığı ve taç giyme töreninin yapıldığı Fransız Gotik mimari özellikleri taşıyan Magusa'daki St. Nicholas Katedrali ve Lefkoşa'daki St. Sophia Katedrali'dir [23]. Latin Kilisesi, Rum din adamları ve Rum Ortodoks Kilisesi'nin gücünü kontrol altına alarak gelişmesinin önünü kesmiş, ancak kiliselerinin alışılmış şekilde hizmet etmesine izin vermiştir [31].

1571 yılında, Osmanlılar aday1 fethettikten sonra bazı kiliseleri camiye dönüştürmüşler, birkaç yeni cami ve mescit yaptırmışlardır [31]. Bu dönemde Ortodoks Kilisesi yeniden kurulmuş; Osmanlılar, Rum Ortodoks Kilisesi'nin yanı sira Ermenilerin, Nestoryanların ve Maronitlerin kendi kiliselerini korunmaları ve yönetilmeleri için gerekli yasal izinleri düzenlemiş ve ihtiyaç durumunda yeni kilise, manastır, okul ve diğer yapıların inşasına destek olmuşlardır [32]. 19. yüzyıl sonunda İngiliz yönetimi döneminde ise özellikle köylerde çok sayıda kilise inşa edilmiştir. Yönetim bu yapıları ibadet dışında okul olarak kullanıldıkları için desteklemiştir. Ayrıca, İngiliz Hükümeti 1935 yılında Antik/Eski Eserler Dairesini kurarak tarihi yapı envanterleri hazırlatmış ve harap durumdaki bazı tarihi yapılar için restorasyon çalışmaları yürütmüştür [12]. Mağusa surlar içinde bulunan Ermeni Kilisesi gibi bazı dini yapılar onarılmış ve orijinal işlevleriyle kullanılmaya başlanmıştır.

1974 bölünmesinden sonra kuzeyde kalan Hiristiyanlara ait 500 den fazla ibadet yerinin (manastırlar, kiliseler ve şapeller) bir kısmı yeni yerleşen Türk toplumu tarafından camiye dönüştürülmüş ve bir kısmı ise el sanatları atölyesi, folklorik dans merkezi veya anaokulu gibi ibadet dışı kültürel amaçlı işlevlerde kullanılmıştır [33]. Kuzey Kıbrıs'ta 1974 sonrası İskele'deki Panayia Theotokos Kilisesi, Güzelyurt'daki St. Mamas Manastır1, Girne'deki Archangelos Kilisesi gibi birkaç kilise ikon yada arkeoloji müzesine dönüştürülmüştür. Az sayıda kilise ise 1974 yılından bugüne işlevini sürdürmektedir. Adadaki iki toplum tarafindan da kutsal sayılan Apostolos Andreas Manastır1, kuzeyde kalan Rumlar tarafindan bugün de kullanılan Dipkarpaz'daki Ayios Synesios Kilisesi ve Koruçam'da bulunan Ayios Georgios Maronit Kilisesi gibi birkaç kilise kendi toplulukları tarafından hala kullanılmaktadır. Ancak, sadece adanın kuzey kesiminde kalan envanterlere kayıtlı kiliselerin sayısının 512 olduğu düşünüldüğünde çok sayıda kullanılmayan ve bu nedenle de bakımsız hatta zaman içinde kısmen veya tamamen yıkılmış kilise bulunduğu 
anlaşılmaktadır. Kıbrıs Rum toplumu terkedilen bu kiliseler için uluslararası komisyonlara raporlar sunmuş ve hukuki işlem başlatmıştır $[34,35]$.

Bir sonraki başlık altında, 1974 yılında adanın bölünmesinden önce ve sonraki dönemde kilise yapılarının camiye dönüştürülme süreci incelenmiştir. $\mathrm{Bu}$ inceleme uygulama sürecinin dinamikleri anlamaya katkı sağlamanın yanı sıra bu dinamiklerin siyasi anlaşmazlıklardan, savaşlardan ve hala çözüm sağlanmamış Kıbrıs sorunundan nasıl etkilendiğini vurgulamaktadır.

\subsection{Kuzey Kıbrıs'ta Kiliselerin Camiye Dönüştürülme Süreci}

Yukarıdaki bölümlerde bahsedildiği üzere Kıbrıs'ta kiliselerin camiye dönüştürülme süreci, Arap fethi döneminde başlamış ve bu uygulamayı daha önce Anadolu topraklarında da yapmış olan Osmanlı İmparatorluğu döneminde tekrar etmiştir. 1974 sonrasında adada yaşanan benzer süreç bugün yerini camiye dönüştürülmüş kiliselerin bulunduğu köylerde yeni camilerin yapımına bırakmıştır. Aşağıda bu süreçler detaylı olarak açıklanmaktadır.

\subsubsection{4 Öncesi Süreç}

$\mathrm{Bu}$ bölümde 1974 y1lı öncesinde camiye dönüştürülen kiliseler iki kategoriye ayrılarak incelenmiştir: Cami olarak kullanılmaya devam eden ve bugün farklı işlevlere hizmet eden kiliseler. Adadaki erken dönem kiliselerinden bazılarının Pers-Arap Müslümanları'nın istilası sırasında 12. yüzyıldan önce camiye dönüştürüldüğü bazı kaynaklarda belirtilmektedir [36]. Ancak bu sürece ait yeterli bilgi kaynağı olmadığı için Osmanlı döneminden günümüze kadar geçen süreç incelenmiştir.

\subsubsection{Camiye Dönüştürülmüş ve Günümüzde Cami Olarak Kullanılan Kiliseler}

Osmanlı döneminde camiye dönüştürülmüş kiliselerden en iyi bilinen örnek Mağusa'da bulunan ve 1571 y1lında Osmanlı fethinden sonra camiye dönüştürülen Saint Nicholas Katedrali/ Lala Mustafa Paşa Cami'dir (Şekil 1). Reims'daki
Notre Dame Katedrali'nden esinlenerek inşa edilen katedral [37] ve Kudüs Kralı'na taç giyme töreninin yapılması nedeniyle Hıristiyanlar için önem taşımaktadır [38]. St. Nicholas'ın oldukça iyi işlenmiş Gotik mimari etkili batı yöndeki giriş cephesinin iki yanındaki çan kulelerinden kuzeydekinin yerine yapı camiye dönüştürüldükten sonra zarif bir minare yapılmıştır (Şekil 1).

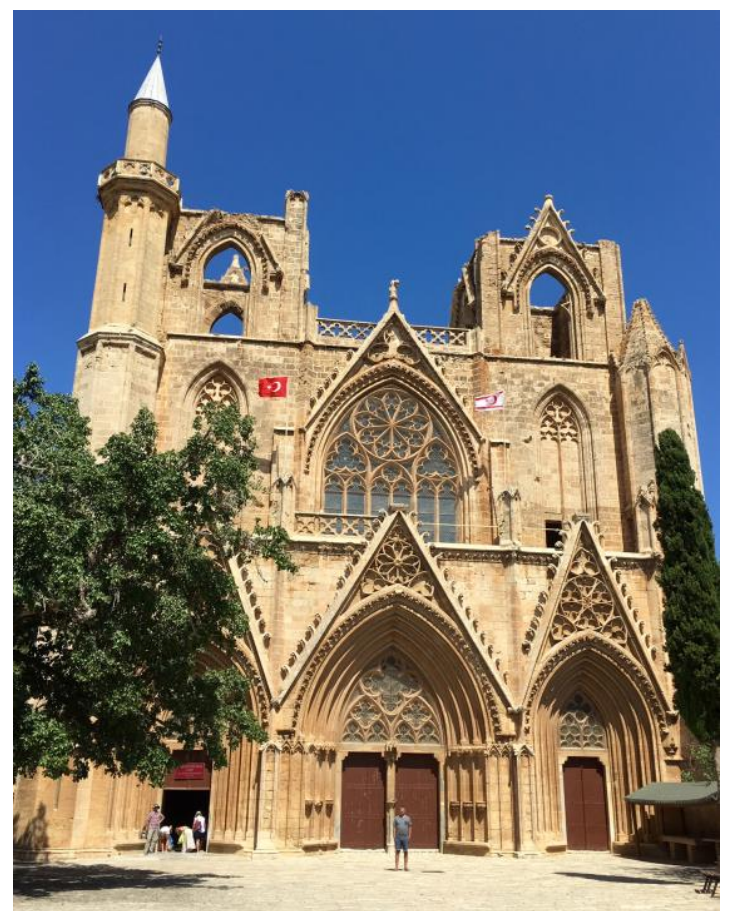

Şekil 1. Saint Nicholas Katedrali/Lala Mustafa Paşa Cami-Gazimağusa

Yapının cephesinde ve iç mekanında Hristiyan dinine ait İsa, Aziz ve melek tasvirleri ile referanslar kaldırılmış, iç mekan beyaz renkte boyanmıştır (Şekil 2). Ayrıca, yine tasvir süslemeli vitray camlar kaldırılarak yerine mermer soyut desenli oyma paneller yerleştirilmiştir. İç mekanda güney duvar üzerine mihrap nişi eklenmiş, ahşap bölme ile kadınlar mahfili tanımlanmıştır. Mermer zemin kıble yönünde seccade şeklinde dokunmuş ve ibadet sırasında her birey için yer tanımlayan halılarla kaplanmıştır. Benzer şekilde başkent Lefkoşa'daki St. Sophia Katedrali de fetih Sultanı II. Selim'in adı verilerek camiye çevrilmiştir. Selimiye Cami, Sultanı temsil ettiği için iki 
minareli olup iç mekanında tuğra tasvirleri bulunmaktadır.

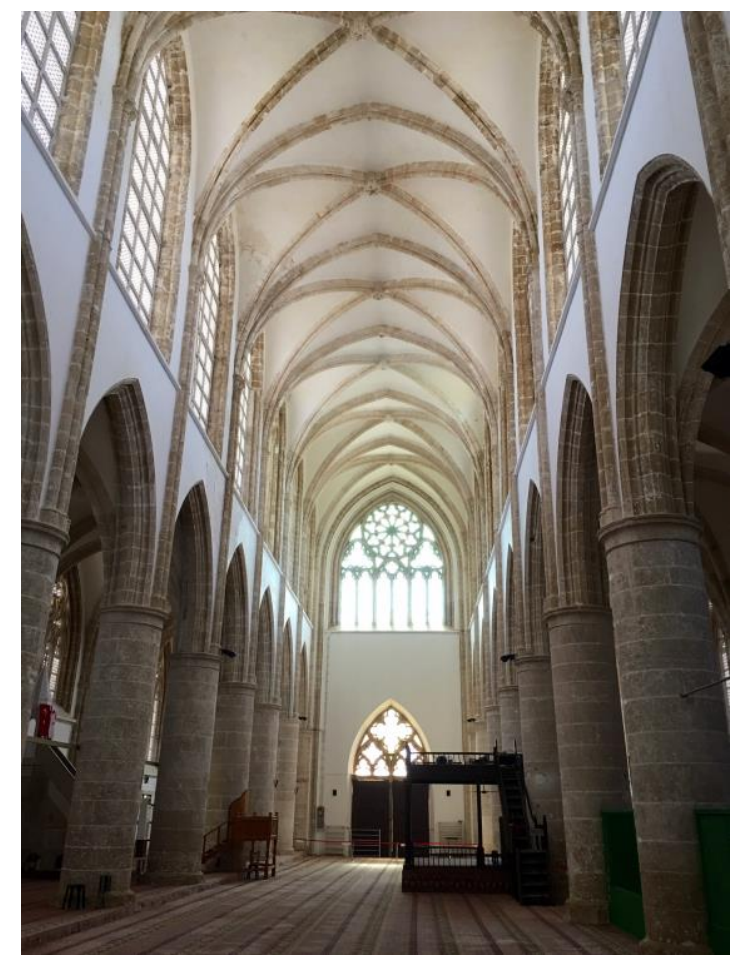

Şekil 2. Lala Mustafa Paşa Cami iç mekan

Osmanlılar fetihten sonra sadece büyük şehirlerde değil küçük kasabalarda da kilise binalarını camiye dönüştürmüşlerdir. $\mathrm{Az}$ sayıdaki örnekten biri Mehmetçik/Galatya'da bulunan Hacı Ahmet Cami'dir. Agia Marina Latin kilisesinden ekler de yapılmak suretiyle camiye dönüştürülmüştür [36]. 1831 yılında yapılan Osmanlı nüfus sayımına göre köyde sadece Türkler yaşamaktaydı. İngiliz dönemi boyunca da hiç kimsenin yerinden edilmediği köyde Osmanlı döneminden bu yana sadece Kıbrıs Türkleri yaşamıştır. Cami'nin cemaat tarafindan aralıksız kullanılması iyi korunmuş olmasını sağlamıştır.

\subsubsection{Camiye Dönüştürüldükten Sonra Farklı İşlev Verilmiş Kiliseler}

$\mathrm{Bu}$ kategoride sadece iki camiye rastlanmıştır. Birinci örnek St. Peter ve St. Paul Kilisesi, bugünkü adıyla Sinan Paşa veya Buğday Cami'dir
(Şekil 3). Mağusa surlar içinde yer alan yapı Latin kilisesi olarak kullanılırken 14. yüzyıl ortalarında Osmanlılar tarafindan camiye dönüştürülmüştür. Yapısal sorunları nedeniyle sonraları ahır, tahıl deposu ve kütüphane olarak hizmet vermiştir. Bir süre boş kalan cami, 2009 yılında USAID'in finansal desteğiyle restore edilerek kültürel amaçlı kullanılmak üzere Gazimağusa Belediyesi'ne devredilmiştir. Yapıldığı dönemin Gotik kiliselerine göre ham ve ağır görünümlü yapının biri batıda diğeri kuzeyde iki girişi vardır. Kuzey girişinin 1940 yılında pencereden kapıya dönüştürüldüğü bilinmektedir [39]. Cami olarak kullanıldığı için iç mekanda fresk ve süsleme bulunmamaktadır. Ancak son restorasyon çalışmaları sırasında Osmanlı döneminde eklenen mihrabın arkasında kalmış fresk izleri bulunmuş ve 2011 yılında restore edilmiştir.

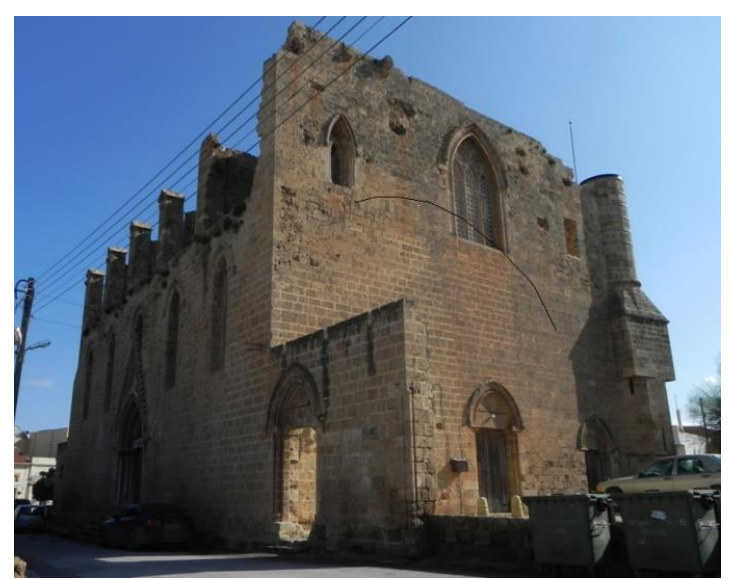

Şekil 3. St. Peter ve St. Paul Kilisesi/Sinan Paşa Cami-Gazimağusa

İkinci örnek 14. yüzyılda kadınlar manastırının parçası olan ve Lüzinyanlar tarafından yaptırılmış Lefkoşa'daki St. Catherine kilisesidir (Şekil 4). Gotik dönemi yansıtan taş oyma süsleme ve tasvirler ile Lefkoşa'daki ikinci büyük kilisedir. Osmanlılar Ağalar Camisi olarak adlandırdıkları bu yapıyı dönüştürürken bazı öğeler eklemişlerdir. $\mathrm{Bu}$ değişim sırasında iç mekandaki özgün taş işçiliği detayları alçı ile tamamen kapatılmıştır. Ayrıca tasvirli vitray camlar delikli alçı panellerle değiştirilmiştir. Yeterli 1şık elde etmek için zemin seviyesinde duvar boyunca büyük kare pencere açıklıkları oluşturulmuştur. Kıbrıs Vakıflar İdaresi 
tarafından restore edilmeye başlandıktan sonra, 1950'li yıllarda yap1 evlilik ve kayıt ofisi olarak kullanılmıştır. 1986 ve 1991 yıllar arasında tekrar restore edilmiş ve Haydar Paşa Cami olarak yeniden adlandırılmıştır. Günümüzde sanat galerisi ve müze olarak kullanılmaktadır.

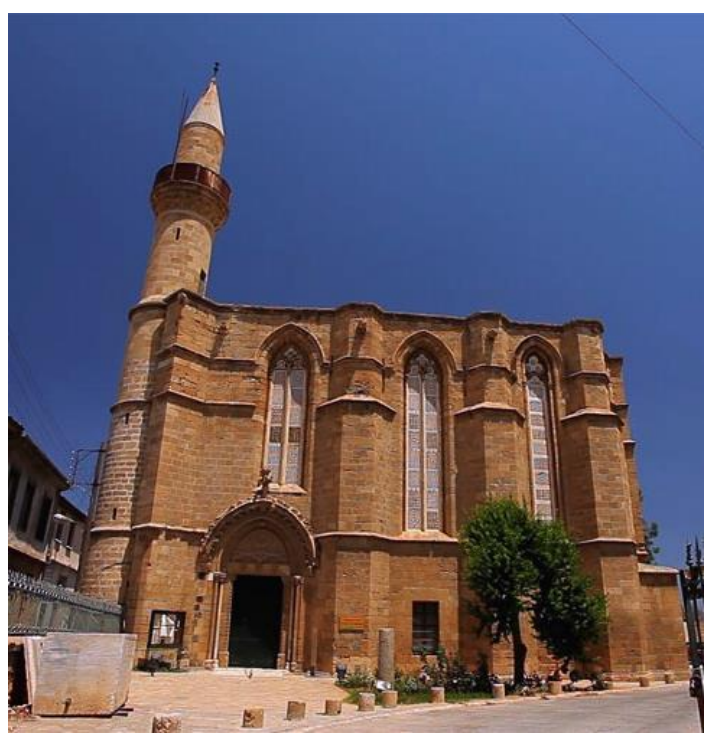

Şekil 4. St. Catherine Kilisesi/Haydarpaşa CamiLefkoșa

\subsubsection{Sonrası Sürec}

1974 yılında adanın bölünmesinden sonra 50 tanesi halen kullanımda, 20 tanesi terkedilmiş 70 adet kilise camiye dönüştürülmüştür (Kıbrıs Vakıflar İdaresi'nden alınan bilgilere dayanarak). $\mathrm{Bu}$ bölümde camiye dönüştürülen ve hala cami olarak kullanılan ve camiye dönüştürülüp kullanılmalarına rağmen günümüzde işlevsiz olan kiliselerden ikişer örnek sunulmuştur.

\subsubsection{1974'den Sonra Camiye Dönüştürülen ve Günümüzde Cami Olarak Kullanılan Kiliseler}

Bugün halen cami olarak kullanılan ve 1974 yılı sonrasında dönüştürülmüş kiliselerden biri Değirmenlik'de bulunan Panayia Chardakiotissa Kilisesi'dir. Günümüzde Başpınar Cami olarak bilinmektedir. 1831 nüfus sayımlarına göre köy ağırlıklı olarak Hristiyan Rumlara ev sahipliği yapmıştır. Günümüzde ise ağırlıklı olarak çoğu Trabzon'dan getirilmiş Türk göçmenler ve adanın güneyinde yer alan Larnaka bölgesinden göç etmek zorunda kalmış Kıbris Türkleri yaşamaktadır. 1902 yılında inşa edilmiş köydeki en büyük kilise olan yap1 1975 yılında camiye dönüştürülen ilk kilisedir. Gunnis'e göre [38], kilisenin galerisinde 17. yüzyıla tarihlenebilecek simgeler bulunmaktayd1, ancak günümüzde yapının iç mekanında orijinal tasvirlerden, duvar resimlerinden veya süslemelerinden hiçbir ize rastlanmamaktadır. İç mekanda duvarlar beyaz badana yapılmış, taş zemin halı ile kaplanmış, güney duvara mihrap eklenmiştir. Ahşap minber ise daha sonra yapılan bir eklemedir (Şekil 5). Kilisenin dışında ise çan kulesinin üzerine eklenen küçük ölçekli minare haricinde pek bir değişiklik yapılmamıştır.

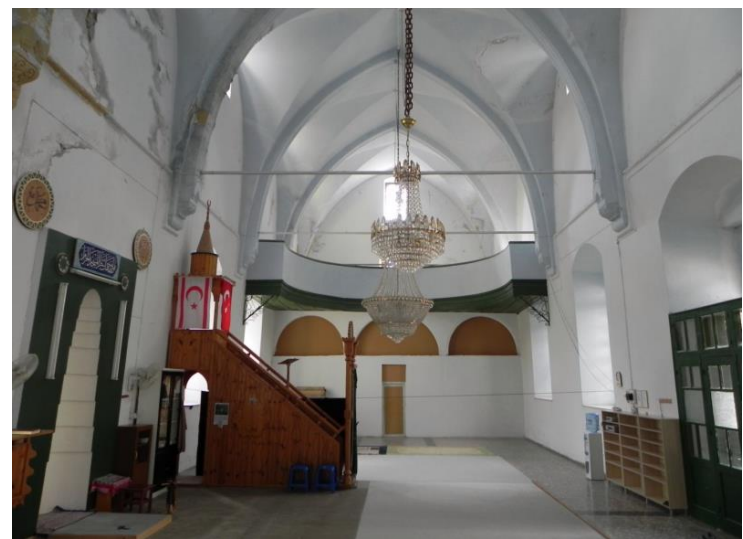

Şekil 5. Panayia Chardakiotissa Kilisesi/Başpınar Cami iç mekân-Değirmenlik

Diğer bir örnek ise Akdoğan/Lysi'daki Panayia Theotokos Kilisesi'dir. 1831 yılına ait Osmanlı nüfus sayımına göre köyde sadece Rumlar yaşamaktaydı. 1974 yılı sonrasında köye güneyden göç eden Türkler yerleşmiş ve köy merkezinde bulunan kiliseyi camiye dönüştürmüşlerdir. Bugün hala cami olarak kullanılan yap1 19. yüzyılda yapılmış olmasına rağmen tamamen gotik mimari etkisiyle tasarlanarak inşa edilmiştir. Köy halkı yapının mimari niteliklerine duyulan hayranlık nedeniyle diş kütlede değişiklik yapılmadığını sadece çanın çıkarıldığını belirtmişlerdir. Ezan için 
yerleştirilen hoparlörler ise yapıya zarar vermeyecek şekilde merkez kubbenin önüne yerleştirilen metal dikme üzerindedir.

\subsubsection{1974'den Sonra Camiye Dönüştürülen ve Günümüzde Terkedilen Kiliseler}

1974 yılından sonra camiye dönüştürülen 70 kiliseden 20 tanesi 1991 den bu yana yapılmakta olan yeni camiler nedeniyle cemaatini kaybetmiş ve terkedilmiştir. Bu çalışmada sunulan ilk örnek yap1 Mormenekşe'de bulunan Agios Nikolaos Kilisesi'dir (Şekil 6). 1831 nüfus sayımına göre köyde yaşayanların tümü Rumlardan oluşmaktaydı. İngiliz Hükümeti döneminde nüfus durumu değişmemesine rağmen, 1974'de köyde yaşayanların yerine Larnaka bölgesinden göç eden Kıbrıs Türkleri yerleştirilmişlerdir. Daha sonraları, 1976 ve 1977 yıllarında, çoğunlukla Adana'dan gelen Türk nüfus da köye yerleşmiştir. Mormenekşe Köyü kilisesinin geçmişi, kuzey cephede yer alan giriş kapısı üzerindeki kitabesine göre 1863 yılına dayanır. Kiliseyi özel kılan bir karakteristiği doğu duvarındaki İsa kabartmalarıdır. Bu kabartmalar camiye dönüşüm sürecinde yok edilmemiştir. Kilise Kıbrıs Türklerinin gelmesiyle 1975 yılında camiye dönüştürülmüş ve 2010 yılına kadar kullanılmıştır. Günümüzde ise köye yapılan yeni cami Müslüman Türk toplumunun ibadet ihtiyacını karşılamaktadır.

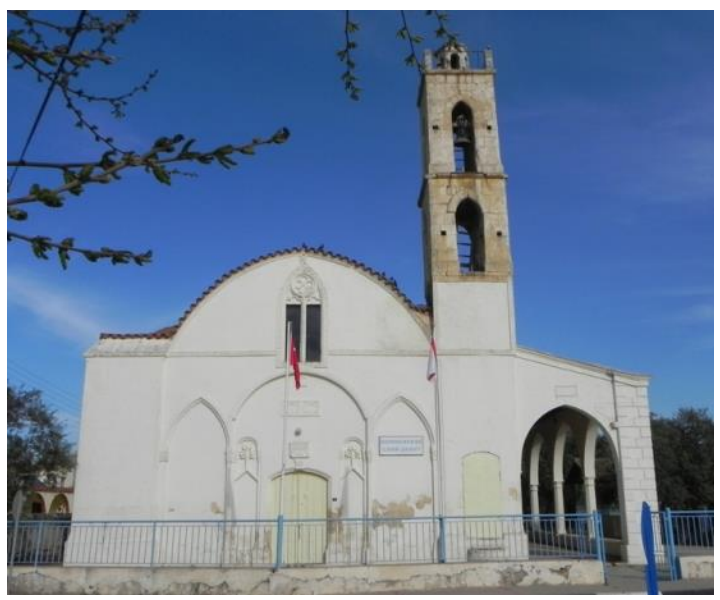

Şekil 6. Agios Nikolaos Kilisesi/Mormenekşe Köyü Cami
Bir diğer örnek ise Karpaz/Karpas yarımadasında bulunan Pamuklu/Tavrou'daki Agios Sergios kilisesidir (Şekil 7). Bu köyde de 1974 y1lı öncesinde sadece Rumlar yaşamaktaydı. 1974 yılı sonrasında ise Pamuklu Köyü Giresun, Ordu ve Yozgat'tan göç eden Türklere ev sahipliği yapmıştır. Köyde bulunan Agios Sergios Kilisesi silindirik bir kasnak üzerine yerleştirilmiş kubbe ile örtülü geniş kütlesiyle 19. yüzyılın tipik bir örneğidir. Ayrıca kilisenin batı cephesinin her iki yanında çan kuleleri vardır. 1974 sonrasında camiye dönüştürülmüş, ancak 2010 yılında hemen yanına yeni cami yapıldığı için terkedilmiştir.

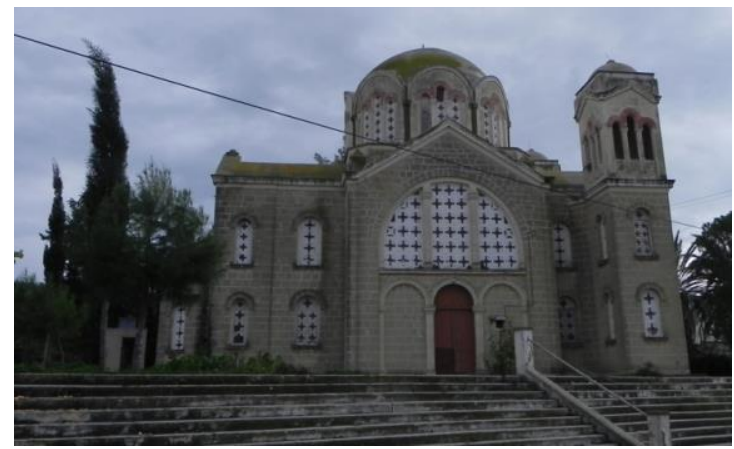

Şekil 7. Agios Sergios Kilisesi/Pamuklu Köyü Eski Cami

\section{ADANA}

Adana eski çağlardan beri pek çok uygarlığa ev sahipliği yapmış, özellikle antik dönemde içinde bulunduğu Kilikya bölgesi ve yakınındaki Antakya/Antioch Hiristiyanlığın Anadolu'da ilk yayıldığı yerlerden biri olmuştur. Bugün hala Adana'nın komşu kentleri Antakya ve MersinTarsus Hıristiyanlar için kutsal alanları barındırmaktadır. Adana'da kiliseden camiye dönüştürülen yapılar üç alt başlıkta incelenmiştir. Öncelikle Adana'nın kısaca tarihi hakkında bilgi verilmiş, daha sonra Adana'daki dini kültür varlıkları değerlendirilmiştir. Üçüncü alt başlıkta ise kiliseden camiye dönüştürülme süreci Adana kent merkezi ve il sınırları içinde yer alan yapılar ele alınarak açıklanmıştır. 


\subsection{Adana'nın Kısa Tarihi}

Çukurova bölgesinin eski yerleşimlerinden biri olan Adana'nın tarihi merkezindeki Tepebağ höyüğünde yapılan çalışmalara dayanarak kentin geçmişini MÖ 6000'lere yani Neolitik Çağa dayandırmak mümkündür. MÖ 1191-1189 yıllarında Hitit hükümdarlığının çökmesi ile başlayan süreçte batıdan gelen saldırılar nedeniyle bölgeyi küçük krallıklar kontrol altında tutmuştur [40]. Pompey dönemi sırasında kent Kilikya korsanları için hapishane olarak kullanılmış ve bundan sonraki birkaç yüzyılda doğuya giden Roma ordusunun güzergahında önemli bir istasyon olmuştur. Roma İmparatorluğu'nun 395 y1lında kalıcı olarak bölünmesini takiben kent Bizans İmparatorluğu'nun bir parçası olmuştur [40].

Ortaçağda Adana'da farklı uygarlıklar hüküm sürmüştür. Bunlar sırasıyla; 7.yy'ın ortalarında Araplar, 964'de Bizanslar, 1071'den sonra Selçuk Türkleri, 1097'de ilk Haçlilar, 1132'de Kilikya Ermeni Krallığ1, 1137'de Bizans güçleri, 1170 civarında da Ermenilerdir [41]. 1268 yilında bu bölgede birçok şehrin yıkımına neden olan ciddi bir deprem olduğu bilinmektedir. Adana deprem sonrası yeniden inşa edilmiş ve 1359 yılına kadar Kilikya Ermeni krallığının parçası olarak kalmıştır [41]. Bu tarihten sonra kent Misır Memluklerinin eline geçmiş ve birçok Türk ailesinin bu bölgeye yerleşmesine olanak sağlamıştır. Rönesans dönemi sonundan yeniçağa kadar (1571-1918), Adana ve çevresi Osmanlı İmparatorluğu hakimiyetindedir. I. Dünya Savaşı sonrası 20 Ekim 1921 tarihinde Fransa ile Ankara Antlaşması imzalanmıştır. Antlaşmanın koşulları temel alınarak, Fransa Kilikya savaşının son bulduğunu kabul etmiş ve Fransız birlikleri kalan Ermeni birlikleri ile 5 Ocak 1922'de geri çekilmiştir.

\subsection{Adana'da Dini Mirasın Olușumu}

Adana'nın dini mirası temel olarak Kilikya bölgesinde egemen olmuş farklı uygarlıkların inşa ettiği erken dönem Hristiyan mabetleri, camiler ve 18-19 yüzyıllara ait kiliselerden oluşmaktadır. Kutsal topraklara yakınlığından dolayı Anadolu'nun özellikle güney doğu kesimi pek çok Hristiyan Azizin (örneğin; Paul of Tarsus,
Nicholas of Myra, Polycarp of Smyrna vb.) doğum yeri olarak önem taşımaktadır [42]. Bölgeyi önemli kılan bir diğer konu ise Hıristiyanlığın beş merkezinden ikisinin Türkiye'de olmasıdır; Constantinople (İstanbul) ve Antioch (Antakya). Antakya, Saint Peter'in kendi yaptığı ilk ve bugün de var olan en eski kiliselerden birine sahip olmanın yanı sıra tarihte İsa'ya inananların ilk kez "Hristiyan/Christians" olarak adlandırıldı ğ 1 yerdir [42]. Ayrıca, Doğu ve Batı kiliselerinin her ikisi tarafından da tanınan 7 Ekümenik Konseyin ilki Anadolu'da düzenlenmiştir [43]. 325'de İznik Konseyi ile ilan edilen İznik ya da İnanç Akdi günümüz Hristiyanlığının gerekli tanımlamalarını bildirmesi nedeniyle son derece önemli sayılmaktadır [44]. Farklı mezheplere bakıldığında Türkiye'de Bizans, Ermeni, Suriye, Latin ve Anglikan kilisesi mevcuttur.

Adana vilayeti ele alındığında ise Osmanlı döneminde Müslümanların çoğunlukta olduğu, ancak Hristiyan ve az sayıda Yahudi toplumunda yaşadığı görülmektedir [45]. Müslümanlardan sonra en kalabalık nüfusu Hristiyanlar oluşturmakta, dolayısıyla kentte farklı mezheplere ait kiliseler bulunmaktadır. Osmanlı döneminin hemen öncesinde St. Jacques kilisesi camiye dönüştürülmüştür. Bugün Yağ Cami olarak bilinen yap1 o dönemde Eski cami olarak anılmaktayd1. Osmanlı döneminde, Adana şehir merkezinde yer alan 8 kilisenin ikisi Ermeni, biri Ermeni Katolik, biri Rum, biri Latin, biri Suriyeli Katolik, biri Suriyeli Yakubi ve biri de Keldani Katoliklere, tapınak ise Protestanlara aittir [45,46]. 1905 yılına ait Osmanlı Şark Yıllıklarında tapınak ve kiliselerden sorumlu kişilerin isimleri verilmiştir $[45,46]$. Kaynağa göre iki Ermeni kilisesinden Sahak Babayan, Ermeni Katolik kilisesinden Terziyan, Keldani kilisesinden Pere Stephan, Latin kilisesinden R. P. Jouve, Suriye Katolik kilisesinden Phillippos, Suriye Yakubi kilisesinden P. Betres ve Protestan tapınağından ise B. Chambres sorumlu idi [46].

Yukarıda sözü edilen 8 kiliseden günümüze kadar gelenler, etnografya müzesi olarak kullanılan Rum Kilisesi ve faaliyetini sürdüren Bebekli Kilisedir. Bu kilise, 1881 yılında St. Paul adına yaptırılmış olan İtalyan Katolik Kilisesidir [47]. Diğer 
kiliseler ise, I. Dünya Savaşı sırasında tahrip olmuş veya kullanıcısı olan topluluklar göç etmiştir. Göçle birlikte kilslerin bir kısmı işlevsiz kalmıştır. Örneğin, 1915 yılında Osmanlı içişleri bakanı Mehmed Talat Anadolu'nun doğusunda (Osmanlı yönetimi altında) ve savaş bölgesi yakınında yaşayan bütün Ermenilerin Suriye ve Musul'a gönderileceğini ilan etmiştir [48]. Bu kararı takiben taşınabilir malların satışı ve tüm mal ve mülklerin yönetimi için tasfiye komisyonları kurulmuştur. Kilise ve manastırlar gibi kutsal yerler kamulaştırma, dönüştürme uygulamalarının dışında tutulmuştur [48]. Dini yapıların ve kiliselerde bulunan mevcut eşya, resim ve kutsal kitapların kaydedileceği ve korunabileceği bildirilmiştir. 1915 yılı Kasım ayında yapılan yeni bir düzenleme ile tavsiye işlemleri tamamlanan okul ve manastırlardan gelen malzeme ve belgelerin kullanımı Milli Eğitim Bakanlığına devredilmiş; yapıların mülkiyeti ise devletin uhdesine verilmiştir [49]. Savaş sırasında tahrip olan veya kullanıcıları olmadığı için işlevsiz kalan kiliselerin yerine imar faaliyetleri sırasında yeni yapılar inşa edilmiştir.

\subsection{Adana'da Kiliselerin Camiye Dönüştürülme Süreci}

Adana kent merkezi ve il sınırları içinde yapılan saha çalışmalarında kent merkezinde 1 ve dışında 1 adet olmak üzere iki camiye dönüştürülmüş kiliseye rastlanmıştır. $\mathrm{Bu}$ yapılara ait bulgular aşağıda sunulmaktadır.

\subsubsection{Kent Merkezi}

Adana tarihi kent merkezinde camiye dönüştürülmüş tek kilise bugün Yağ Cami olarak bilinen St. Jacques Kilisesi'dir (Şekil 8). Evliya Çelebi, Seyahatnamesinde yapıdan Eski Cami adıyla söz etmektedir. Ramazanoğlu Halil Bey tarafindan 1501 yılında kiliseden camiye çevrildiği, daha sonra yapının avlusu etrafında yer alan son cemaat yeri, taç kapısı ve medresesinin oğlu Piri Paşa tarafından yaptırıldığı bilinmektedir [50]. Caminin kuzeybatı köşesinde yer alan minaresi 1525 yılında yaptırılmış ve 1941 yılında yenilenmiştir [50].

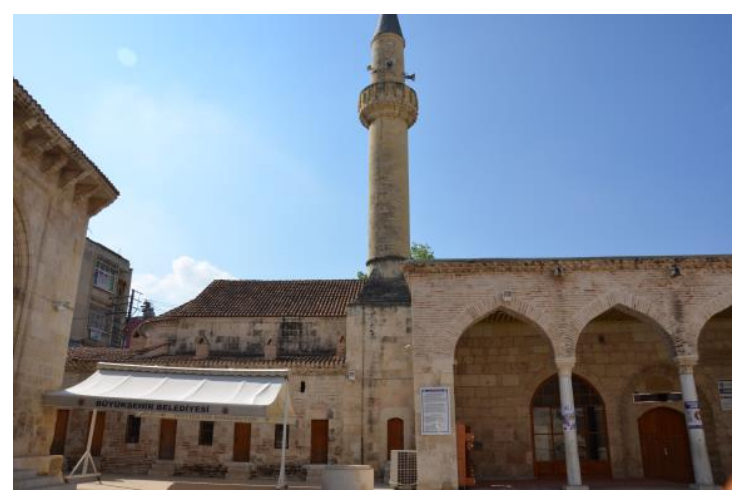

Şekil 8. Yağ Cami/St. Jacques Kilisesi

Bugünkü haliyle yap1 $1000 \mathrm{~m}^{2}$ nin üzerinde geniş bir parsel üzerinde $375 \mathrm{~m}^{2}$ si kapalı alandan oluşmaktadır. Kuzey yönde büyük bir avlu ve bu avlu içerisinde medrese yer alır (Şekil 9). Yağ Camii Külliyesi'ni oluşturan yapılar mimari kompozisyonları, yapım teknikleri ve büyüklükleri açısından farklıdır. Bu farklı kütleler arasında doğu yöndeki dairesel apsis uzantısıyla daha önce kilise olan kısım fark edilmektedir. Bu bölüm minarenin hemen arkasındadir.

Camiye dönüştürülürken kilisenin ana giriş kapısı genişletilerek batı yönde ulu cami plan tipinde bir ek inşa edilmiştir. Kilisenin iç mekânı ve ek yapı birleşerek caminin harim kısmını oluşturur. Özgün yapının kütlesine oranla oldukça büyük inşa edilmiş ekler nedeniyle bugün kilise yapısını algılamak pek mümkün değildir; ancak doğudaki apsis bölümü dışardan görülebilmektedir.

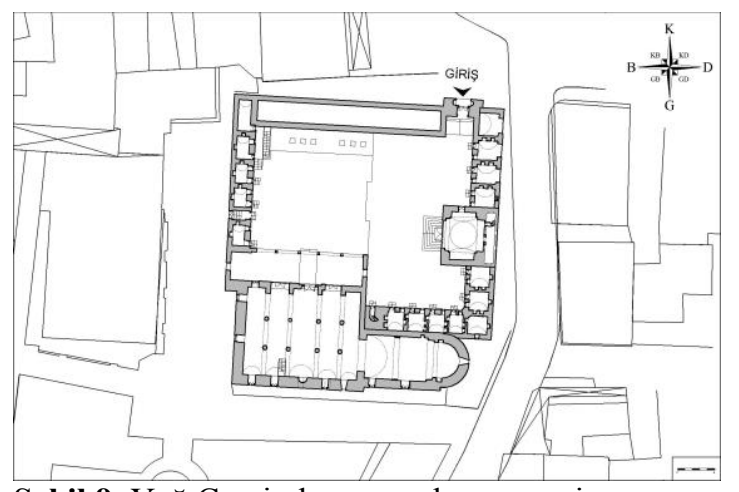

Şekil 9. Yağ Cami planı ve yakın çevresi 


\subsection{2. İl Sınırı İçi}

Adana il sınırları içinde Kozan İlçesi Kıbrıslar Köyü’nde kiliseden camiye dönüştürülmüş bir yap1 bulunmaktadır. Kıbrıslar Köyü Cami hakkında yazılı bilgiye ulaşılmamıştır. Mimari niteliklerine dayanarak kilisenin Bizans dönemine ait olduğunu ve zaman içinde değişikliklere uğradığını söylemek mümkündür. Bugünkü haliyle özgün kilise yapısının kuzey duvarına bitişik tek katlı betonarme ek yapılmak suretiyle kullanım alanı genişletilmiş, güney duvarın bir kısmına bitişik olarak da imam için konut inşa edilmiştir (Şekil 10).

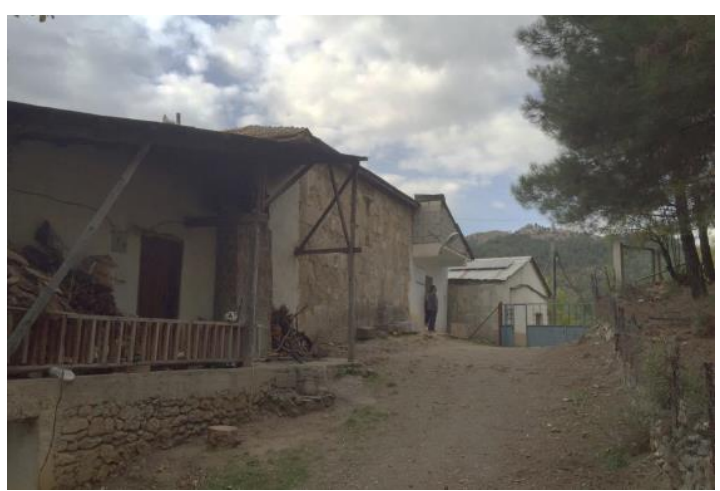

Şekil 10. Kıbrıslar Köyü Cami doğu yönde giriş cephesi

Yapı dış kütlesi bakımından kilise tipolojisine uygun izlenim vermemekle birlikte bu durumun zaman içinde yapılan değişikliklerden kaynaklandığı söylenebilir (Şekil 11). Yap1 eğimli bir arazi üzerinde konumlanmakta ve bugün üst kottan giriş almaktadır. Ancak, alt kotta yapının önceki dönemlerine ait izler barındıran güney yönde bir giriş daha mevcuttur. Tonozlu bir mekânla geçilen alt kotta yapının önceki dönemde de cami olarak kullanıldığını gösteren güney duvarda mihrap nişi bulunmaktadır. $\mathrm{Bu}$ niş yukarıda bugün kullanılan mekânda yer alan mihrap nişi ile aynı aks üzerindedir. Yapı bugün tespit edemediğimiz ancak detaylı araştırma ve belgeleme çalışmaları sonucu anlaşılabilecek nedenlerle kısmen yıkılmış ve ahşap döşeme dikmelerle üst kota taşınmıştır (Şekil 12).

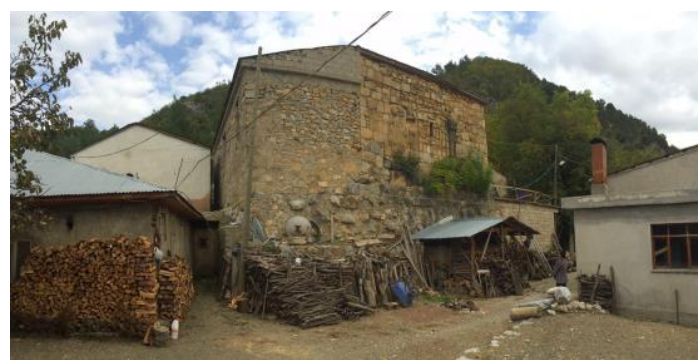

Şekil 11. Kıbrıslar Köyü Cami batı cephe

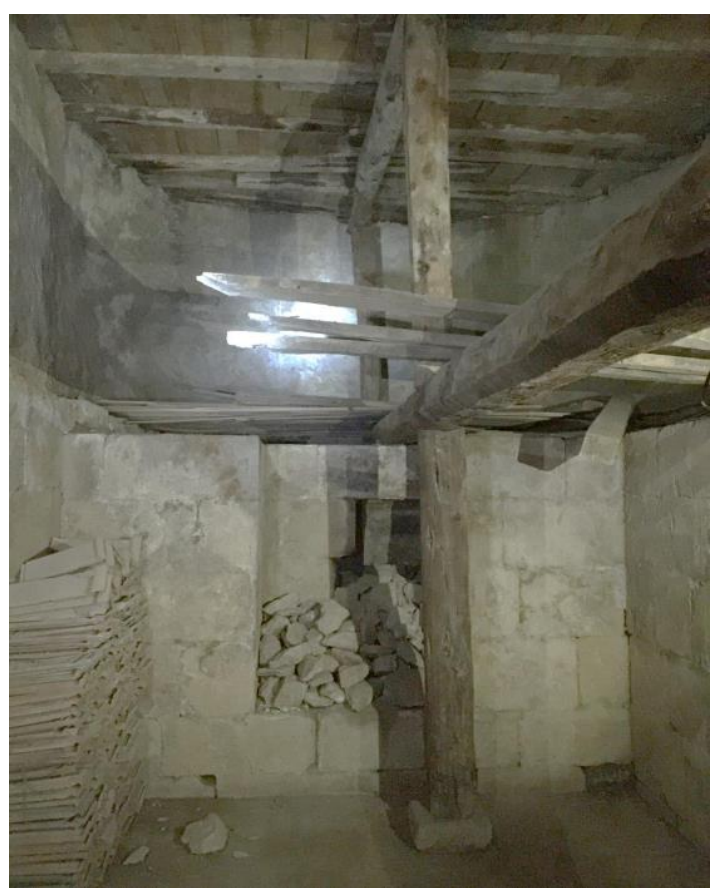

Şekil 12. Kıbrıslar Köyü Cami alt kot iç mekân

\section{DEĞERLENDİRME}

Yukarıda incelenen örnekler kilise yapılarının cami olarak kullanılmak üzere dönüştürülmesi sürecinin, tarihsel dönem ve kültür ile ilişkisini anlaşılmasına olanak sağlamıştır. İncelenen alanlardan Kibrıs'ta 50, Adana'da ise 2 kilisenin camiye çevrildiği görülmektedir. Adana örneğinde kiliseden camiye çevrilen yapı sayısının az olmasının bir nedeni geç dönem kiliselerinin çoğunun yıkılmış olmasından kaynaklanmaktadır. Ülkemizin diğer illerinde bu tür uygulamalar daha çok Osmanlı döneminde yapılmış, Cumhuriyet kurulduktan sonra gündeme gelen mübadele 
sonucunda boşta kalan kiliselerin bir kısmı yıkılmış, bir kısmı ise cami olarak veya kültürel amaçlı yeniden işlevlendirilmiştir. Bu örneklerin çoğu İstanbul'da yer almaktadır.

Adana'daki iki yapıdan Kıbrıslar Köyü Cami, bulunduğu coğrafi konumun zorluklarından dolayı yeni yapı inşa etmek yerine mevcutta kullanılmayan, atıl bir kilisenin camiye dönüştürülmesiyle günümüze ulaşmıştır. Bugün yapıyı kullanan köy nüfusu az sayıda olsa da bakımı yapılmaktadır. Yağ Cami ise kent merkezindeki konumu nedeniyle atıl birakılmak yerine dönüştürülmüş bir yapıdır. I. Dünya savaşı sırasında Adana'da yaşan Hristiyan toplumun bir bölümü göç etmiş ve kiliseler atıl kalmıştır. Süreç içinde tahrip olan altı kilise imar faaliyetleri sırasında yok olmuştur. Az sayıdaki Latin kökenli kiliselerden biri hala kilise diğeri ise müze olarak kullanılmaktadır.

Kıbrıs'ta ise çoğunlukla 1974 sonrasında kiliseler camiye dönüştürülmüştür. Osmanlı dönemine ait örnekler sayıca azdır. Bu durum, 1974 yılı sonrası yaşanan belirsizlik sürecinin uzamasından kaynaklanmaktadır. Ada ikiye bölündükten sonra tekrar birleşme olasılığ 1 sürekli gündemde kalmış ve iki toplumda daha önce yaşadıkları köylere dönebilme ihtimaline dayanarak geride kalan mülklerinin geleceği hakkında karşılıklı empati kurmuştur. Saha çalışması sırasında görüşülen yerel halktan kişiler bu kaygı nedeniyle yerleştirildikleri köylerdeki Rumlara ait yapılara zarar vermediklerini ve korunmaları için kullanımın gerekli olduğunu belirtmişlerdir. Ancak, zorunlu göçün hemen sonrasında bazı kiliselerin ahır olarak kullanıldığı, daha sonra çıkarılan bir yasa ile bu tür kullanımların yasaklandığı bilinmektedir. Kiliselerin camiye dönüştürülmesinde önemli bir etken de adada Osmanlı döneminde bu uygulamanın yapılmış olmasıdır. Osmanlılar genellikle fethettikleri yerlerdeki en önemli ve en büyük kiliseyi seçerek camiye dönüştürmüştür. Kıbrıs Lefkoşa'daki St. Sophia ve Mağusa'daki St. Nicholas Katedralleri bu durumu kanıtlamaktadır. Güç simgesi olarak sultanın adı "Selim" başkentteki en görkemli katedrale verilmiş ve 1571 yılından günümüze St. Sophia Katedrali Selimiye Cami olarak adlandırılmıștır. Benzer șekilde Mağusa'daki en görkemli ve Kıbrıs'taki ikinci önemli katedrale de Mağusa surlarını fethetmek için bir yıldan fazla savaşan komutanın adı "Lala Mustafa Paşa" verilmiştir. $\mathrm{Bu}$ iki önemli örneğin dışında Osmanlılar köylerde çok az sayıda kiliseyi dönüştürmüş yerine yeni cami yapmayı desteklemişlerdir. Bu dönemde Kıbrıs'ta yapılan camiler Anadolu'da inşa edilenlerle kıyasla mütevazı örneklerdir. $\mathrm{Bu}$ bilgiler 1şı̆̆ında, Osmanlıların kiliseleri dönüştürme sürecine yaklaşımlarında, ibadethanelerin birer kimlik simgesi olarak kabul edildiği ve dolaysıyla yıkmak yerine dönüştürerek kültürel fetih yapıldığı sonucuna varmak mümkündür.

Dönüştürülme sürecinde yapılan fiziksel değişiklikler açısından Kuzey Kıbrıs'taki uygulamalar Adana'daki örneklerle benzerlik göstermekle birlikte, Adana'daki kiliselere dışarıdan yapılan eklerin özgün yapıların kütlesel olarak algılanmasının önüne geçtiği söylenebilir. Bunun dişında yapılan müdahaleler benzer şekildedir: Yap1 bütün Hristiyan simgeler, duvar resimleri, tasvirler, haçlar ve özellikle ibadet edilen alan içindeki hayvan veya insan figürleri, Hristiyanlık dinine ait sembollerden arındırılmıştır. Taşınabilir öğeler kaldırılmış ve tasvirli duvarlar genellikle sıva ve boyayla kapatılmıştır. Mihrap kıbleye yönelimi gösterdiği için gereklidir. İbadet yerde yapıldı̆̆ı için caminin zemini dönüşüm sırasında genellikle halı ile kaplanmıştır. Yapının dışındaki önemli fiziksel düzenleme minarenin eklenmesidir. Bazı örneklerde çan kulelerinden biri minareye dönüştürülmüş ve bazılarında ise yeni kuleler yapılmıştır. Ancak günümüzde kayıttan ezan okunduğu için bazı örneklerde minareler oldukça küçük yapılmış ve üzerine hoparlör eklenmiştir. Kuzey Kıbrıs’taki bazı örneklerde dış kütlede Hristiyanlık sembollerinin kaldırılmadığ gözlenmiştir. $\mathrm{Bu}$ durum, güneyden gelen Türk toplumun bir gün kendi köylerine geri dönecekleri ve kuzeydeki köylerde geçici olarak bulundukları için yapılar üzerinde büyük çaplı değişiklikler yapmaktan kaçınmalarıyla ifade edilebilir. Örneğin, 1974 yılında camiye dönüştürülen ve o zamandan beri kullanilan Tuzla Cami'nin (Şekil 13) çanı bir gün tekrar işlevini görme olasılığı nedeniyle kaldırılmamıştır. 


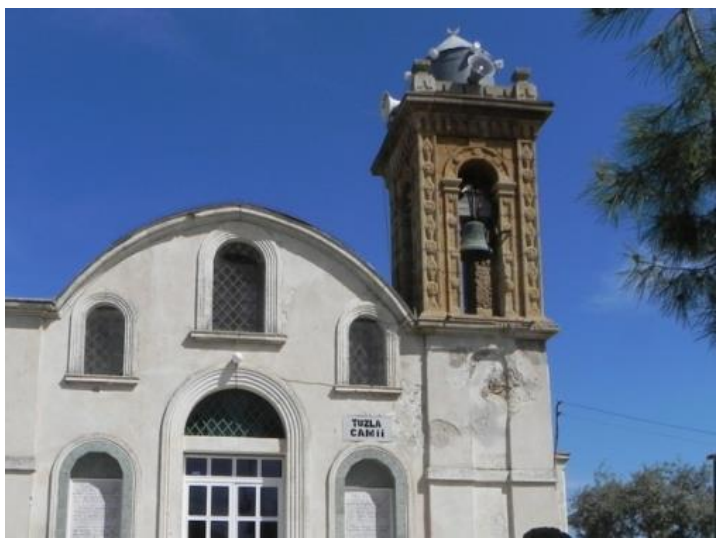

Şekil 13. Tuzla Cami

Kuzey Kıbrıs'ta 1991 den beri, özellikle de kiliselerin camiye dönüştürüldüğü köylerde, yeni camilerin yapımında artış olmuş ve cami olarak kullanılan 20 kilise binası terkedilmiştir. Rum toplumu tarafindan ne kadar eleştirilse de, yapılan çalışma kiliselerin atıl bırakılmak yerine zarar vermeyecek kullanımlara uygun biçimde dönüştürülmelerinin korunmalarında önemli rol oynadığını göstermektedir.

\section{SONUC}

Mimari yapılar belirli işlevlere hizmet etmek üzere inşa edilmelerine rağmen, zaman içerisinde değişen şartlar nedeniyle dönüştürülerek farklı işlevler için kullanılmaları gerekli görülebilmektedir. Bugün, pek çok kent merkezinde fabrika yapıları sanayi alanlarının merkez dişına taşınması nedeniyle atıl kalmış ve yeni işlevlere uygun şekilde düzenlenerek tekrar kullanıma açılmışlardır. $\mathrm{Bu}$ tür dönüşüm uygulamaları, mimari korumada dini yapılar özelinde farklı ele alınmaktadır. Dini yapıların yeniden kullanımı konusu yapının arz ettiği dini, sembolik ve sosyal değerlerinden ötürü, fiziksel adaptasyonun dışında yapının somut olmayan değerlerinin de detaylı analizini gerektirmektedir. Dini yapılar ait oldukları toplumların simgeleri olmaları nedeniyle bulundukları coğrafyayı fetheden ve farklı inanç mensubu toplumlarca çeşitli şekillerde korunmuş ya da yok edilmiştir. Osmanlı İmparatorluğu gibi çok uluslu medeniyetlerde fethedilen yerlerdeki en görkemli birkaç kilise güç simgesi olarak camiye dönüştürülmüş, diğerleri var olan Hıristiyan cemaatin kullanımına bırakılmıştır. Kıbrıs'taki Selimiye ve Lala Mustafa Paşa Camileri bu uygulamanın önemli örnekleridir. Diğer yandan, beraber yaşayan, ancak farklı dini inançlara sahip toplumlarda çıkan çatışma ve savaşlarda dini yapılar düşman olarak görülen diğer toplumu simgelediği için, anlaşmazlığın doğasına da bağlı olarak, çoğunlukla yok edilmiştir. Adana'da 16 yüzyılda kiliseler camiye çevrilmek yoluyla kullanılırken, 20 yüzyılda durum farklılık göstermektedir. Bu dönemde anlaşmazlık yaşanan toplumu simgeleyen kilise yapıları yıkılmıştır. Kıbrıs'ta yaşanan çatışma ve sonrasındaki bölünmenin doğası ise farklılıklar arz etmektedir. 1974 yılı sonrası yaşanan belirsizlik durumu ve kaynakların kısıtlı olması nedeniyle mevcuttaki yapılar kullanılma yoluna gidilmiştir. Ayrıca, adada kiliselerin camiye dönüştürülmesini örnekleyecek Osmanlı dönemi uygulamaların mevcudiyeti de halkın bu durumu kabul edilebilir olarak algılamasına yol açmıştır. Kiliseleri camiye dönüştürme sürecinde yapılan fiziksel müdahalelere bakıldığında Adana'daki örneklerde yapıların kütlesel olarak algılanmasının önüne geçildiği görülmektedir. Kuzey Kıbrıs'taki örneklerde ise kiliseler mimarileriyle dışarıdan algılanabilmektedir. Hatta bazı örneklerde Hıristiyanlık simgesi mimari elemanlar kaldırılmamıştır. Bu durum, Kıbrıs'taki iki toplumun, ayrı sınırlar içinde yaşasalar da, tekrar birleşme olasılığı nedeniyle varlıklarını kabul etmelerinin bir göstergesi olarak yorumlanabilir. Adanın güney kesiminde kalan camiler Rumlar tarafından kullanılmamıştır. Ancak, yapıların kullanılmaması bir yandan da koruma sorununu ortaya çıkarmaktadır. Kuzey Kıbrıs'ta incelenen camiye dönüştürülmüş kiliseler kullanıldıkları için bakımları yapılmış ve yapısal bozulmaya uğramadan günümüze gelmişlerdir. Son dönemlerde yapılan yeni camiler, dönüştürülmüş çok sayıda kilisenin boş kalmasına neden olmuştur. Kuzeyde yer alan kiliselerin toplamda sayılarının beş yüz kadar olduğu düşünüldüğünde, bu yapıların korunmaları kültürel mirasın sürdürülebilirliği açısından önemli bir sorun teşkil etmektedir. 2003 y1lı sonrası yapılan iki taraflı görüşmeler sonucunda kurulan İki Taraflı Kültürel 
Miras Komitesi ve Birleşmiş Milletler Kalkınma Fonu Kibris Ofisi'nin de teknik ve finansal desteğiyle kuzeyde ve güneyde kalan dini yapıların restorasyonu yürütülmektedir. Yapıların bütüncül korunmaları için bu tür siyasi anlaşmazlık olan bölgelerde tarafsız uluslararası kuruluşlar önemli rol oynamaktadır. Adana örneğinde ise kiliseler bölgenin çok kültürlü geçmişini yansıtan önemli bir mimari miras öğeleridir. İlçelerde yer alan kısmen yıkılmış kiliselerin mevcut durumlarının belgelenerek, öncelik sırasıyla korunmaları için yapılacak girişimler bu varlıkların gelecek kuşaklara aktarılmasına yardımcı olacaktır.

\section{TEŞEKKÜR}

Bu çalışma, Adana Bilim ve Teknoloji Üniversitesi BAP Birimi tarafından GSTM 2014-1 proje koduyla desteklenmiştir.

\section{KAYNAKLAR}

1. Addis, B., 2007. Building: 3.000 Years of Design, Engineering, and Construction, Phadion Press, London.

2. Kostof, S., 1995. A History of Architecture: Settings and Rituals, Oxford University Press, Oxford.

3. Douglas, J., 2006. Building Adaptation, Routledge, London.

4. Harris, J.A., 1997. Mosque to Church Conversions in the Spanish Re-conquest, Medieval Encounters 3 (2) 158-172.

5. Walls, A.F., 1996. The Missionary Movement in Christian History: Studies in the Transmission of Faith, Orbis Books, New York.

6. Khoury, N., 1996. The Meaning of the Great Mosque of Cordoba in the Tenth Century, Muqarnas, 13 (1) 80-98.

7. Mills, H. M., 1991. The pre-Islamic provenance of the mosque of Cordoba, AlMasaq: Journal of the Medieval Mediterranean, 4 (1) 1-6.

8. Eyice, S., 1986. İstanbul'un Camiye Çevrilen Kiliseleri, Taç, 1 (2) 9-18.

9. Eyice, S., 1990. İstanbul'da Kiliseden Çevrilmiş Cami ve Mescidler ve Bunların
Restorasyonu, Vakıf Haftası Dergisi, 7, 279291.

10. Güney, Y.I., 2008. The Mosques in Ayvalık: Appropriating the Lost Post of Kynodie, Traditional Dwellings and Settlements Working Paper Series, (205) 43-64.

11. Y1lmaz, E., Eroğlu, S., 2013. Edessa'dan Urfa'ya: Urfa'da Kilise'den Camiye Dönüştürülmüş Yapılar, S.D.Ü. Fen-Edebiyat Fakültesi Sosyal Bilimler Dergisi 30, 1-12.

12. Hyland, A.D.C., 1999. Ethnic Dimensions to World Heritage: Conservation of the Architectural Heritage of the Turkish Republic of Northern Cyprus, Journal of Architectural Conservation 5 (1) 59-74.

13. Herscher, A., 2000. Monument and Crime: The Destruction of Historic Architecture in Kosovo, Grey Room, 1, 108-122.

14. Kinley, J.C., 2004. Convert! Adaptive reuse of churches. Master Thesis. Massachusetts Institute of Technology.

15. Bevan, R., 2006. The Destruction of MemoryArchitecture at War. London: Reaktion Books.

16. Velthuis, K., Spennemann, D.H.R., 2007. The Future of Defunct Religious Buildings: Dutch Approaches to Their Adaptive Re-use. Cultural Trends, 16 (1), 43-66.

17. Ross, M.H., 2007. Cultural Contestation in Ethnic Conflicts. Cambridge: Cambridge University Press.

18. Constantinou, C.M., 2007. Aporias of Identity: Bicommunalism, Hybridity and the Cyprus Problem. Cooperation and Conflict, 42 (3) 247 270.

19. Herscher, A., 2008. Warchitectural Theory. Journal of Architectural Education, 61 (3), 3543.

20. Chotzakoglou, C.G., 2008. Religious Monuments in Turkish Occupied Cyprus: Evidence and Acts of Continuous Destruction. Lefkoşa: Kykkos Monastery.

21. Lueg, R., 2011. Houses of God or Not?! Approaches to the Adaptive Reuse of Churches in Germany and the United States. Unpublished Master Thesis. University of Maryland.

22. Arbel, B., 2000. Cyprus, the Franks and Venice, 13th-16th centuries, Tel Aviv University Press, Tel Aviv. 
23. Hill, G., 1948. A history of Cyprus, Volume II: The Frankish Period, 1192-1432, Cambridge University Press, Cambridge.

24. Given, M., 2000. Agriculture, Settlement and Landscape in Ottoman Cyprus, Levant, 32 (22) 209-230.

25. Oberling, P., 1989. The Cyprus Tragedy. K. Rüstem and Brother, Lefkoşa.

26. İsmail, S., 1989. 1974 Öncesi -1974 Sonras1, Kastaş A.Ş. Yayınları, İstanbul.

27. Jeffery, G., 1918. A Description of the Historic Monuments of Cyprus, Government Printing Office, Lefkoşa.

28. Enlart, C., 1987. Gothic Art and the Renaissance in Cyprus, Trigraph, London.

29. Goodwin, J.C., 1978. A Historical Toponymy of Cyprus, Jack C. Goodwin, Lefkoşa.

30. Edbury, P.W., 1991. The Kingdom of Cyprus and the Crusades, 1191-1374, Cambridge University Press, Cambridge.

31. Jennings, R.J., 1993. Christians and Muslims in Ottoman Cyprus and the Mediterranean World, 1571-1640, New York University Press, New York.

32. Benedict, E., 1995. Studies on the History of the Church of Cyprus 4th-20th Centuries, Ashgate Publishing, Brookfield.

33. Saifi, Y., Yüceer, H., 2013. Maintaining the Absent Other: The Re-use of Religious Heritage Sites in Conflicts, International Journal of Heritage Studies, 19 (7) 749-763.

34. Grieboski, J.K., Porter, K.C., 2009. Written Testimony: Helsinki Commission Hearing on Cyprus' Religious Cultural Heritage in Peril, The Institute on Religion and Public Policy, Alexandria.

35. Yüceer, H., 2012. Protection of Abandoned Churches in Northern Cyprus: Challenges for Reuse, Protecting Cultural Heritage in Times of Conflict, eds. S. Lambert, C. Rockwell, ICCROM, Rome; 60-66.

36. Bağışkan, T., 2009. Ottoman, Islamic and Islamized Monuments in Cyprus. Cyprus Education Foundation, Nicosia.

37. Walsh, M.J.K., 2005. A Gothic Masterpiece in the Levant: Saint Nicholas Cathedral, Famagusta, North Cyprus, Journal of Cultural Heritage 6 (1) 1-6.
38. Gunnis, R., 1956. Historic Cyprus: A Guide to its Towns and Villages, Monasteries and Castles, Methuen, London.

39. Walsh, M.J.K., 2004. Saint Peter and Paul Church (Sinan Pasha Mosque), Famagusta: A Forgotten Gothic Moment in Northern Cyprus. Inferno, (9) 1-8.

40. Hallo, W.W., 1971. The Ancient Near East: A History. New York: Harcourt Brace Jovanovich.

41. Edwards, R.W., 1987. The Fortifications of Armenian Cilicia: Dumbarton Oaks Studies XXIII. Washington, D.C., Dumbarton Oaks, Trustees for Harvard University.

42. Peacock, A.C.S., Nicola B., Yildiz, S. N., 2015. Islam and Christianity in Medival Anatolia, Ashgate, London.

43. Harl, K.W., 2001. From Pagan to Christian in Cities of Roman Anatolia During the Fourth and Fifth Centuries, Urban Centers and Rural Contexts in Late Antiquity, Michigan.

44. Mitchell, S., 1993. Anatolia, Land, Men and Gods in Asia Minor II, The Rise of the Church, Oxford.

45. Çatal, A.C., 2016. II. Abdülhamid Döneminde Adana'nın Sosyo-Ekonomik Yapısı, Yayınlanmamış Kitap.

46. Annuaire Oriental du Commerce, 1905. Şark Ticaret Y1llkkları-1905. The Annuaire Oriental \& Printing Company Limited, Londra.

47. Özmen, Y., Özerol, M.E., 2000. Adana'nın Simgeleri, Efsaneden Tarihe, Tarihten Bugüne Adana: Köprübaşı (Editörler: Erman Artun, M. Sabri Koz), İstanbul, Yapı Kredi Yayınları No: 1392, 156-167.

48. Polatel, M., 2009. Turkish State Formation and the Distribution of the Armenian Abandoned Properties from the Ottoman Empire to the Republic of Turkey (1915-1930), Unpublished Thesis, Koç Üniversitesi Graduate School of Social Sciences and Humanities, İstanbul.

49. Üngör, U.Ü., Polatel, M., 2011. Confiscation and Destruction: The Young Turk Seizure of Armenian Property, Continumm International Publishing Group, Londra.

50. Çam, N., 2010. Kültür Varlıkları Envanteri Adana-01, Türk Tarih Kurumu Yayınları, Ankara. 
